\title{
Love, Erotic Art and the Moral in the Albanian Socialist Realism
}

\author{
Ermir Hoxha \\ University of Tirana, Faculty of History and Philology, \\ The Department of Heritage and Culture \\ E-mail: ermirhoxha@yahoo.com
}

\section{Doi:10.5901/mjss.2014.v5n3p613}

\begin{abstract}
During the centuries, the concept of eros has been modified and alongside this transformation was modified also the relationship it has with the art, but whereas in the world art, during each historical period, the examples of erotic art are multiple, in our native tradition, for the major part of it, this art remains in the limits of a taboo, both visually and spiritually. In Enver Hoxha's Albania, the campaign for the "deportation" of old customs waged war to the format of patriarchal family and together with it, it waged war also to its conception. Similar to a massive propaganda campaign synchronized between all the media, the state chose to promote the youth's love, as a promoter of the new man's spirit, who at his basis would build the new family, the structure foundation of the socialist society. But in the socialist style love, certainly there was no place for the "supplementary" elements: eros and sensuality. As for the nature of the proletarian dictatorship itself, they remained foreign elements, because the state's mission was the elevation of the new man who would put himself in the service of the ideological cause.
\end{abstract}

Keywords: Socialist Realism, love, modern, eros, taboo.

\section{Albanian Patriarchalism, Isolation and General Retrogradation}

"Like every form of art, erotic art too is destined to touch "the strings" of the feelings; it is born from the internal need and the desire to express the universe of the passion and emotions" (Zulli, 2001: 7). Through the centuries, the concept of erotic art itself has been modified and together with it, it is transformed also the relationship it has with art. As it can be easily understood, it was born together with the human being and it is present with it since the prehistoric representations of the human figure, as a testimony of the significant importance it has upon the society itself (Zulli, 2006: 5). But whereas in the world art, during each historical period, the examples of erotic art are multiple, in our native (Albanian) tradition, for the major part of it, this art remains in the limits of a taboo, both visually and spiritually. This is due to the fact that the moralizing tradition during the centuries, at first the byzantine and then the ottoman one, cultivated a bifid morality in the Albanian gene, split between the Muslim fanatism and a lighter Christian conservatism. However, in both versions, it coexisted with the oriental despotic reality, where the patriarchalism naturally found its terrain, in the discriminating politics, isolation and general retrogradation.

During the centuries, the only spaces left for the expression of the sensual nature are identified in the spiritual heritage, in the epic legends, songs, myths and legends, where characters like the nixes, mountain fairies or the nymphs of the lake, carried occasionally elements of the erotic nature (Çeta, 1974: 34). Transmitted as legends, they are enriched, to come till at the XIXth century as a synthesis of the spirit of a people, which like every other one, beyond patriarchalism has cultivated the desires of the body and of the spirit. ${ }^{1}$ In the $X X^{\text {th }}$ century, the whole process of the gathering, catalogation and analysis has entered into scientific basis, initially from the intellectuals of the ' $30 \mathrm{~s}$, and later in the cathedra's of the Albanological sciences.

Beyond the implied erotic elements, which are also present in the cultural inheritance, many works that have been realised in the first decades of the century have represented men or women half or fully naked, often as nudes for art school lessons and on other times as works realised in the local artists studio. In any case, the tradition of the nude in the Albanian art, would find its genesis at the work of the photographer Pietro Marubi, when unidentified women would pose, with or without shyness, their charms in front of the cameras of the time (Qerimi, 2005). At one or another version, the

${ }_{1}$ Parallel with a lot of native authors, during the XIXth century, there were a lot of materials and studies on mythology and faith among Albanians which were published from foreigners like Boue, Ami. 1840. La Turquie de l'Europe - vol. II, (Paris: Chez Bertrand), Hahn, G. J. 1854. Albanesische Studien. (Jena: B.d. 1.3), or Hahn, G. J 1866, Greek and Albanian folk tales, (Leipzig, B.d. 1-2) 
history of the Albanian nude climbs the XXth century with timidity, as a consequence of the inherited age-long morale, the minimal level of education and contacts with the Western world and all those other elements of retrogression that the Albanian society suffered till at the wake of the new century.

\section{Eros and Love in the Albanian Socialist Realism}

Enver Hoxha, the self-defined architect of the new Albania (after WW2), among the numerous plans he had for the county and his countrymen, certainly dreamed also the dissociation from the oriental past, offspring of the which was the cultural revolution of the " 60 s. Continuing the "deportation" of the old customs, he declared "war" to the patriarchal format of the family and together with it, to its conception. As such, it was strongly condemned the matchmaking marriages or worse the one in which the bride was promised till at the time when she was a baby, whilst was made a great deal of propaganda about the love between the youths, freed from social, religious or cultural distinctions. A by-product of this was the "order" that every new (modern) Albanian couple had the "blessing" of the party's morale to fight against the old mentality and triumph in the name of love. As a mass propaganda campaign, synchronized in all media, every young Albanian had to fight for himself and the others, while the artists, in the first line of the state's propaganda, had to cover this theme in their products (novel, painting, artistic movie and documentaries). Along with testimonies and appeals published in magazines and newspapers, their message was multiplied to promote vigorously the new standards of the Albanian society, which normally had its roots in the liberation war. ${ }^{2}$

The results during this decade were impressive. The Albanian youths, ablaze from the passion of the students that had come from the schools of the Eastern Europe, starting from the beginning of the ' $60 \mathrm{~s}$, were demanding radical generational changes, testimony of which were the images of girls with short skirts, boys with long hair and bell-bottoms, the "effusive" music and a contagious youthful enthusiasm, very much beyond the Albanian traditional norms. This cooling breeze, "surprizingly" in tune with the youthful movement in all the world, brought a superposition of norms that were admirable in their quality (above the patriarchal mentality in the country), and was kept alive till at the beginning of the '70s. When the situation was at the peril of going out of control, the Albanian state intervened with the notorious Plenum (Hoxha. E, 1973), but the already initiated platform continued to be implemented, for a definitive departure from the tribal and patriarchal past. Even though not with the same enthusiasm of the ' 60 s, testimony of this tendency were the continuing echoes of it in literature and written media, as always supported and sponsored from the state's attention. Their typical reflection is visible in movies like: "The Happy Couple", "The Captain", "Why does this drum beat", (Hoxha. A, 1987: 15) or novels or drama in which, unceasingly was pointed out the element of the war against conservatism in the Albanian society, as a reflection of a chapter that was now being concluded.
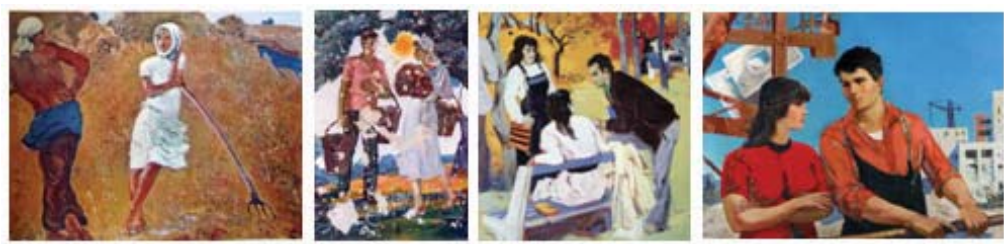

S. Shijaku, "Knowing Each-Other", oil S. Capo, "?" fresco, detail V. Kilica, "Students", oil, 1985 (detail) M. Fushekati, "Sunny Days", oil, 1980

The visual art certainly would offer its contribution also for this theme, even though a minimal one. In fact, the paintings that want to deal with spiritual or physical love between two youths are rare in the works of the Albanian artists. Often they come to us freed in the beginning of the ' 70 s and indolent after the ' 73 cataclysm, to be re-ignited one more time without many pretensions during the '80s. In a simplified version, the artists represent it... the long-awaited moment when two youths almost casually meet. This is what we see at Sali Shijaku's painting, "Knowing each-other", where the boy and the girl, reclining on their working tools, "are lost" for a moment with each-other, sun-burned, and also "burned"

\footnotetext{
2 In the thousands of paintings that would represent the National-Liberating war, the figure of the female partisan soldier would always accompany the male one, major or minor, as an all-inclusive war, with obvious elements of the social emancipation, where equality among fighters was at the center of the attention. It is brought into paintings with various themes, like the school or the partisan theatre, where is emphasized the progress of the country in contrast with the monarch-oriental past. You can see GAF. 1978. Artet Figurative Shqiptare - piktura, Tiranë: 8 nëntori, or GAF. 1969. Artet figurative në Republikën Popullore të Shqipërisë, Tiranë: Naim Frashëri.
} 
from the healthy moral distance of the time. In the background, the artist dares to put also two horses, one blue and one pink, as they caress each-other, like would like, but can't, our "heroes". As a format of the compensation law, Shijaku builds a simple painting, where the symbol of the pre-act of love, stays inside the promoted canons. More simply are represented the youths from Sotir Capo. They are in the month of love, harvesting cherries. Kilica re-encounters them as students for the restarting of school and Fushekati portrays them meeting with each-other at a building site under the burning sun, and so on ... the examples follow one another: like always, with healthy youths, simply dressed, as they communicate between each-other more with their glances than with their gestures. Their frozen conversations have to cover the sexual tension that is spontaneously raised, but at the same time is offered as the new format of going beyond the values of that generation, when the youths now dare and can speak between them without being criticized for displaying a harmful morale.

Even more concealed sensual elements are to be found in other paintings, where the theme is not anymore a date between two youths, but simply, moments during work, where the workers, in a straining way, slip "accidentally" in implied erotic notes. As such are to be distinguished the workers of Pandi Mele, which, while the wind curls their hair, carelessly display a femininity in the boundaries of an atypical sensuality. To them are "attached" the group of girls that are irrigating, dabbling or sowing wheat. Being elegant and complete they are very different from the asexual image of the workers in the turnery, the cooperative women with hoes in their hands or improvised women soldiers in the military trainings.
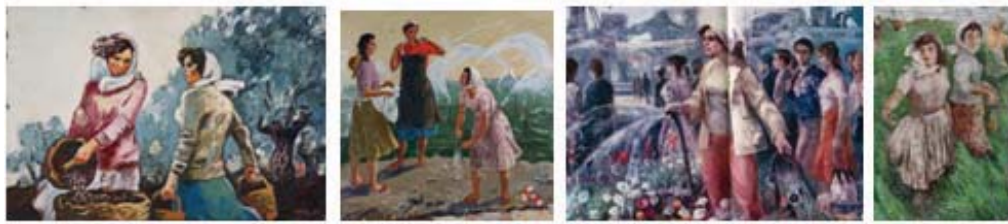

P. Mele "Friends from a brigade", oil, 1982 M. Saro, "The Irrigation", oil A. Dine, "Mornings", oil, 1982 S. Kamberi, "Bread from our hands", oil, 1976

Even though all this must be understood as a need of the artists to represent even a little of the femininity of everyday life, for the state's moral they remained the cliché characters of the accepted stereotypes and as such, healthy parts also of the social morale. On the other side, as the moral was conceived in this form at the canvass or at the celluloid, the party would order through ministerial circulars the preservation of the moral purity, the class position among the "chosen", which should not be seen as a personal matter, but as something that belonged to the socialist revolution.

The power of the stay would play, like always, with two cards, a public and a private one, and to find more explicit works, which glorify, not immorality, but physical love, we need to search a lot, at the point that the result is more searched than found. The attention may be focused only at the "suspicious" glances of the two high-school girls of Fushekati or in a more explicit form between two girls of Buza, as they are putting make-up on their faces. While at the first painting the viewer is intrigued more from the fantasy than from the reality, at the second work the excessive sensuality is felt at the gestures, cheeks and the red lips, at the forms and at glances, till at the point that the characters naturally allow to create the perception that they are being offered to the embodiment of the physical act. Dhimitraq Trebicka seems to propose his absent characters at a more advanced phase. He leaves love waiting to be consumed, as an open hint, not because of the characters, but from two bicycles (again, one is red and the other is blue) parked at the edge of the nature. As a clear parallel of the instinctive call, delicately the artist left to be implied what he can't show, "daring" to provoke without exceeding into the standard moral of the time.
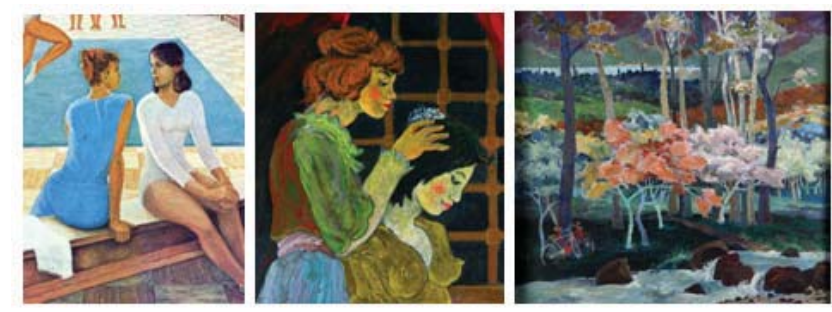

M. Fushekati, "High-School Girls", oil, 1970 (detail) A. Buza, "Make-Up”, oil, 1980, (detail) Dh. Trebicka, "Sunset in Spring", oil 
Sensuality did not remain a taboo among the artists of the Socialist Realism. Without doubt it was drawn from all of them starting from the years at school, where the didactic process would impose the presence of the naked body, to accompany their career in the private studios as souvenirs of a hidden reality. At the impossibility to be exposed on institutions or galleries, they were concealed for years and years as a testimony of a sad censure of the free artistic spirit. Those who suffered the worse fate were the ones whom were to be found with such testimonies, which in their essence were evidence of the sick morale that had contaminated them. Defined as enemies of the class and promoters of the bourgeois degeneration, they had exerted their "hostile" activity during their free time, the private time, where the attentive eye of the state aimed to see. Considered as a serious danger, because it was unknown, it was defined spontaneously as a distant space from the cause. Servet Pëllumbi in 1974 said: "the free time occupies a considerable part of the man's life; if it is used well, can become a source of joy and happiness, a powerful promoter for the general developing of our people. But it may become also something that may uglify the human being, when it is used without any high purpose. This is why the way of using the free time from our people and the purposes for which it is used has been and still remains an arena of the hard class war, an arena of the war for 'their souls' ". (Pëllumbi: 1974: 49)

According to the single road of the party, the multidimensional formation of the new man had to be molded from the deep Marxist-Leninist ideals, the high moral qualities, the wide cultural horizon, the spiritually rich world, the efficiency, the high and unceasingly education and a continual war to improve the material and cultural well-being (A. P. Nikolla, 2012: 66). The state's will believed that these qualities had to be molded only from the paid work, the continual voluntary work and the collective life. Individuality, and with it, the free time represented a real danger, which had to be controlled, while the party's organization and its paraphrase (the school) had to determine since at its genesis, the individual's road and character.

In the society where, until the last hours of the regime, the violent and bloody scenes were censured (like every kiss on the lips), the state's standardized moral asked for a spiritual utopia which hardly could really be kept under control. The true Albanian society existed only on paper as such. It sinned spiritually and physically as every other society, even under the danger of prejudice and persecution.

The imposing of the healthy communist morale, could not eliminate neither adultery, nor corruption, nor theft, nor murder. Even though in extremely minimal numbers, with the power of the state's violence they were maximally bypassed, to be replaced with the same elements, but behind the closed doors, under turned off lights and so, away from the eyes of the voyeurs of the state. For the undisturbed sleep of the public, the censure would filter the information by inflating the good reports and deforming or erasing the bad ones, at the point that covering the truth was turned into a way of living for the conscience of every person. At our country, as everywhere in the East, lying became a system. As Solzhenitsyn would put it: "... daily is the lie at our country - not a caprice of ruined natures, but a form of existence, a condition for the daily well-being of each one of us. The lie is comprised in the state's system, it's its first graft (...). The lie surrounds us at work, on the road, at free time, in everything we see, hear and read." (A. P. Nikolla, 2012: 5)

\section{Conclusion}

The Albanian society, on one side uniformed, and on the other unprecedented in its own world both false and true, as every other society cultivated inside the state's boundaries every possible type of problem. The filtered information of the state offered to the Albanian society only the image of the virtuous man, with a clean moral and ideal (the positive character) who struggled to live only at books. He was materialized there, like in movies and in paintings, but in reality it reflected only the imposed ambition of the social transformation. His antipode (the negative character) was filtered too, from the same filter, taking the face at times of the capitalist, at times of the bourgeois, the priest, the landlord, the rich in different versions, sometimes native and sometimes foreigner. In the internal version of the Socialist Realism they were replaced from the class enemy, the saboteur, the lazy person, the deceiver, the retrograded, the thief, the manipulative, the immoral or the bureaucrat.

As an antipode of the fictive reality, the negative and positive characters fought until the point of the conflict's resolution, which without doubt would be resolved with the victory of the good side, the one that had the communist stamp. The erotic art or sensuality was a foreign element for the very nature of the dictatorship of the proletariat, the great mission of which was the elevation of the new man. This new man would put himself at the service of the ideological cause, would sacrifice himself and everything, by-passing every other spiritual or physical passion. Love between the youths, the only element that would endanger this report was seen as a promoter of the new man's soul, which on love's foundation would build the new family, the structural basis of the socialist society. His love was divided 
more and more often between the fatherland and the party, reduced into just some element-gears of the social structure of the Albanian Socialist Realism.

\section{References}

Boue, Ami. 1840. La Turquie de l'Europe - vol. II, Paris: Chez Bertrand.

Çeta, Anton. 1974. Balada dhe legjenda, Prishtinë: Instituti Albanologjik i Prishtinës.

GAF. 1978. Artet Figurative Shqiptare - piktura, Tiranë: 8 nëntori.

GAF. 1969. Artet Figurative në Republikën Popullore të Shqipërisë, Tiranë: Naim Frashëri.

Hahn, G. J. 1854. Albanesische Studien, Jena: B.d. 1.3.

Hahn, G. J 1866, Greek and Albanian folk tales, Leipzig, B.d. 1-2.

Hoxha, Enver. 1973. Të thellojmë luftën ideologjike kundër shfaqeve të huaja e qëndrimeve liberale ndaj tyre, Tiranë: SHBLP.

Hoxha, Abaz. 1987. Filmi artistik shqiptar 1957-1984, Tiranë: 8 Nëntori.

P. Nikolla, Albert. 2012. Njeriu i Ri Shqiptar. Ndërmjet moralit komunist dhe krizës së tranzicionit, Tiranë: Onufri.

Pëllumbi, Servet. 1974. "Aksioni - mjet për formimin e njeriut të ri", Rruga e partisë. Nr 1. p. 49.

Vrioni, Qerim. 2005. Fotografia një grusht diell, Tiranë: Logoreci.

Zuffi, Stefano. 2006. La storia dell'arte, Le prime civiltà, Bergamo, Electa.

Zuffi, Stefano. 2001. Arte e Erotismo, Milano: Electa. 